Jpn. J. Oral Biol., $30: 144-155,1988$.

\title{
カイウサギの外頸動脈の分枝状況について
}

\author{
八十一博 \\ 大阪菌科大学解剖学教室 (主任 : 太田義邦教授) \\ 〔受付：昭和62年 9 月 1 日]
}

\section{Ramification aspects of the external carotid artery of the rabbit}

\author{
Kazuhiro Yaso \\ Department of Anatomy, Osaka Dental University \\ 47. 1-chome, Kyobashi, Higashi-ku, Osaka, 540 \\ (Director: Prof. Yoshikuni Ohta) \\ [Accepted for publication: September 1, 1987]
}

Key words : External carotid artery/lingual artery/facial artery/occipital artery/rabbit

\begin{abstract}
Ramification aspects of the external carotid artery of the adult rabbit (740 sides) were investigated by means of the acryl plastic injection method. Principal branches of the external carotid were the lingual, the facial and the occipital arteries. Origins of the lingual artery were classified into five types, in reference to other branches of the external carotid as well as the arising features (six types) of the occipital artery. The common carotid artery bifurcated into the external and internal at the height of the middle of the 1st cervical vertebra. The external carotid, in a position lateral to the digastricus and the styloglossus muscles after passing between them, divided into two termini, the maxillary and the superficial temporal at the height of middle of the mandibular ramus, although this position was located more proximal (lower) in about $20 \%$. The lingual and the facial arteries arose independently from the external carotid artery, rarely from the maxillary artery, and via a common trunk (linguofacial trunk) between them. When the facial artery arose from the maxillary artery, the bifurcating height of the common carotid artery was always located more proximally. The occipital artery arose from the vertebral, the internal carotid, the external carotid (as the 1st or 2nd branch), the posterior auricular and the superficial temporal arteries, respectively. When the external carotid was shorter in length since its terminal bifurcation was located more proximally, no branches arose from it.
\end{abstract}

\section{緒 言}

一般にヒトや哺乳動物の頸動脈系, どくに外頸 動脈の諸分枝と終枝分岐については 比較解剖学的 にいろいろの方面から観察されてきた。すなわち 具体的には外頸動脈の終枝分岐の位置, 頭頸部の 形態的差異による諸分枝間の共通幹形成ならびに 起始位置の変化が当面の問題となっている。なか でも実験動物に多用されるカイウサギについて は，古く Baldwin (1919) 1) が頸動脈系の分枝状 態の変化を 12 型に分類した。

大阪市東区京橋 1 丁目47番地（广 540）
著者は当教室に保存されているカイウサギの多 数の頸動脈系の鋳型標本を観察したところ, Baldwin の分類に充当させがたい個体を数多く認め た。本論文は外頸動脈の諸分枝の状況と周囲構造 物との関連を主体として 分類を試みたものであ る。

\section{材料と方法}

成熟カイウサギ370頭（両側740例）について, acryl plastic 脈管注入法 Taniguchi, Ohta et al. $(1952 ， 1955)^{2,3)}$ によって両側総頸動脈から acryl plastic を注入した。うち265頭については $20 \%$ 苛 
性ソーダ水溶液で軟組織を除去し, 頭頸部動脈系 の鋳型標本を作成し，外頸動脈の諸分枝の観察と 計測に供した。残り105頭の注入された材料は10\% ホルマリン液に固定, 剖検標本とし, 分枝と周辺 組織との関連の観察に用いた。

\section{観察所見}

\section{I . 総頸動脈と外頸動脈の概観}

総頸動脈は気管の後外側を第 2 頸椎中央の高さ まで上行し，その前内側壁から内側方一甲状腺動 脈を派出し, さらに平均的には第 1 頸椎中央の高 さで前上方一上喉頭動脈を派出していた。総頸動 脈は，その後壁または後内側壁から後方または後 内側方一向かう細い内頸動脈と, 上方一続く外頸 動脈とに分岐していた（Fig. 1)。

外頸動脈は舌骨大角の後上内側, かつ茎突舌骨 筋と舌下神経の内側，ついで䪽二腹筋の内側を上 行して茎突舌筋下縁に達していた (Fig. 1)。ここ で外頸動脈は上外側方へ曲がり顎二腹筋と茎突舌 筋の間を通って，それらの外側に出て下顎枝中央 の高さで䪽動脈と浅側頭動脈の 2 終枝に分岐して いた (Figs. 1，2)。

顎動脈は茎突舌筋の外側からその上面にでて前 上内側方へ向っていた。一方, 浅側頭動脈は顎動 脈とは反対方向一茎突舌筋にそって後上外側方 向い, 同笳起始の前外側方を上行して外耳孔の前 下外側方に達し，ここで前上方へ向う本来の細い 浅側頭動脈と後上方一向う太い後耳介動脈之なっ ていた (Figs. 1，2)。両動脈の分岐形態はカイウ サギでは極めて特徵的であった。すなわち後耳介 動脈はよく発達して強大であるが，これとは対照 的に浅側頭動脈は逆に発達が悪い。前者は巨大な 耳介に分布し, 後者の主流は顔面横動脈となって いた。

\section{II. 外頸動脈の諸分枝}

外頸動脈が 2 終枝に分岐するまでの主要な 分枝 としては後頭動脈, 舌動脈, 顔面動脈であった。 これらのほかには, 通常ヒトや他の哺乳動物にみ られるような太い恒常的な分枝は認められなかっ た。外頸動脈が 2 終枝に分岐する位置（高さ）は $80.9 \%$ (全観察750例中599例）において, 前述の ように茎突舌筋と顎二腹筋の間の外側方であった
(Figs. 2，3，8，9，11)。残りの19.1\%では，その 位置はさらに近位（低位）に偏していた（Figs. $4 ， 5 ， 12 ， 13)$ 。つづいて外頸動脈から分岐する上 記の 3 動脈それぞれについて，起始様相，とりわ け起始順序, 共通幹の形成, 起始となる親動脈, そしてこれらと外頸動脈の 2 終枝分岐位置との相 関関係を主眼として以下のようにまとめた。

外頸動脈から直接起始する動脈について注目す る。舌動脈と顔面動脈が外頸動脈から起始する場 合は全観察740例中718例 (97.1\%) に認められ， 両動脈の起始の相関関係はつぎのようであった。 両動脈が共通幹，すなわち舌顔面動脈（幹）とし て起始する例は全観察例の $69.9 \%$ に認められ (Figs. 2, 8，9，11)，両動脈がそれぞれ単独で起始 するものは11.1\%であった（Fig. 3)。舌顔面動脈 （幹）や舌動脈の起始は, 常に一定の位置, 寸なわ ち舌骨大角の後上内侧方, しかも舌下神経の内側 であった（Fig. 4)。顔面動脈の起始は外頸動脈の 2 終枝分岐の直前であった（Fig. 3)。一方，舌動 脈が外頸動脈から起始し, 顔面動脈が顎動脈から それぞれ単独で起始する例は $16.1 \%$ に認められた (Figs. 4, 6, 10, 12, 13)。

後頭動脈が外頸動脈から直接起始するものは $52.5 \%$ で，その位置は舌顔面動脈（幹）または舌 動脈の起始の遠位 (45.3\%)（Fig. 2) または近位 (7.2\%) (Figs. 6，11) であった。

全観察例の $2.7 \%$ では外頸動脈からはいずれの 動脈の分岐も認めないまま 2 終枝に 分岐していた (Figs. 5, 7)。

舌動脈と顔面動脈が外頸動脈から起始していな い場合は全観察例740例中22例 (2.9\%) に認めら れた。すなわち舌動脈, 顔面動脈（全観察例中2.0 \%)（Fig．5）が単独で，または舌顔面動脈（幹） (0.9\%) (Fig. 7) としていずれも顎動脈から起始 していた。この状態は外頸動脈の 2 終枝分岐が近 位（低位）である例にのみ認められた。

後頭動脈が外頸動脈から起始していない例は $47.5 \%$ に認められたが，その起始は内頸動脈 $(34.2 \%)$ (Figs. 3，4), 浅側頭動脈 (5.6\%) (Figs. $5,7,13)$, 後耳介動脈 (3.1\%)（Fig. 8), 椎骨動 脈 $(4.6 \%)$ (Figs. 9, 10) であった。

以上のような所見からみて，起始位置および親 
Table 1 Various types of ramifications of the external carotid artery.

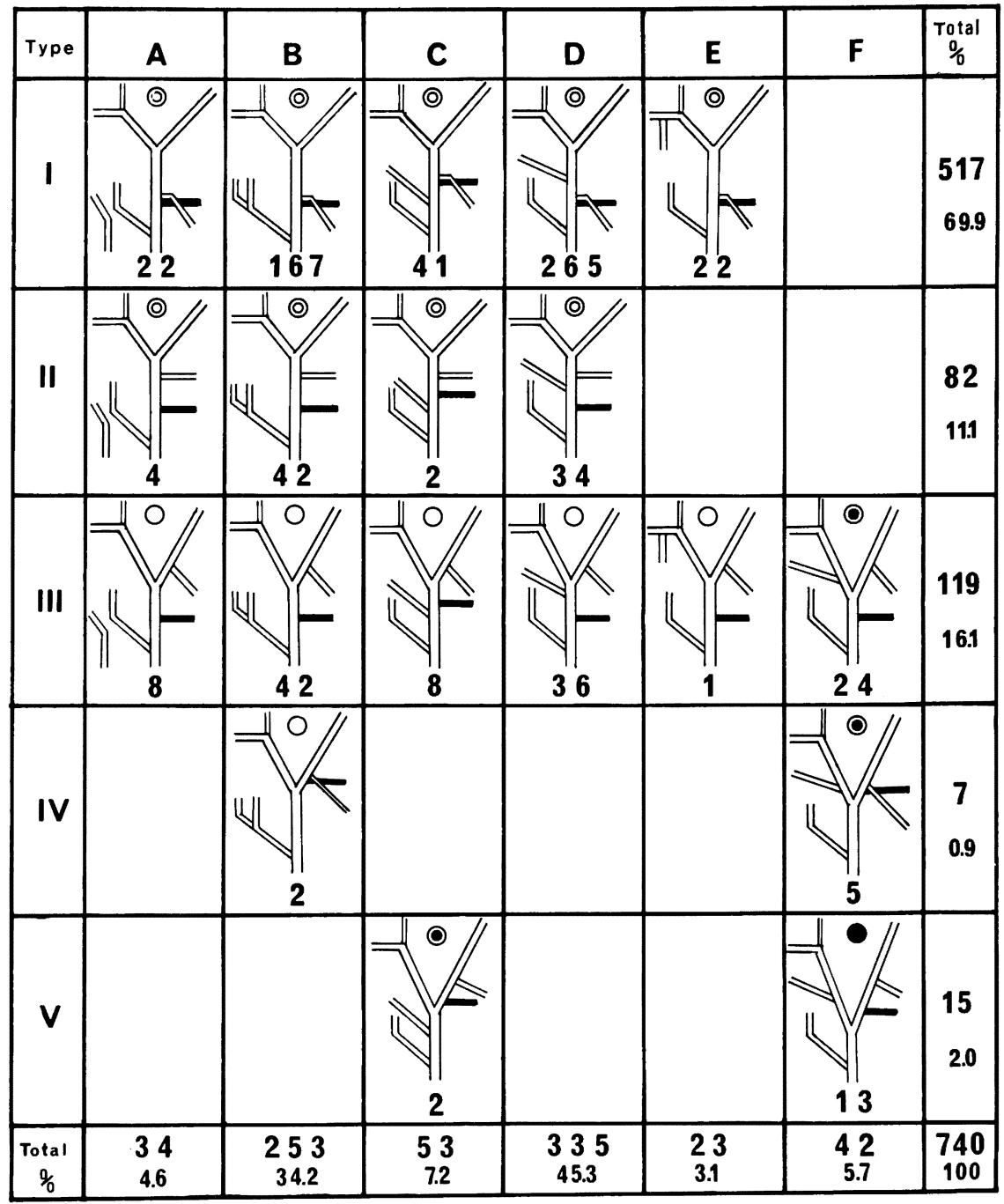

Types $\mathrm{I} \sim \mathrm{V}$ : Arising features of the lingual and the facial arteries.

Types $\mathrm{A} \sim \mathrm{F}$ : Arising positions of the occipital artery.

The following marks indicate positions of the terminal bifurcation of the external carotid. (?) ; Lateral to a position between the digastricus and the styloglossus muscles, $\bigcirc$; Medial to a position between the above muscles, $\bigcirc$; Medial to the digastricus,, $\bullet$; Medial to the hypoglossal nerve. Also, see abbreviations mentioned in page 147.

動脈に変化の少ない舌動脈と，他方，そのような 変化の多い後頭動脈を基隻にして両者の相関関係 を Table 1 にまとめた。

舌動脈と顔面動脈の起始様相については，つぎ のように 5 Types に分類した。

Type 1. 舌動脈と顔面動脈は共通幹である舌 顔面動脈（幹）として外頸動脈から起始。
Type II . 舌動脈と顔面動脈は分離して外頸動 脈から起始。

Type III. 舌動脈は外頸動脈から, 顔面動脈は 影動脈から起始。

Type IV. 舌動脈と顔面動脈は共通幹である舌 顔面動脈（幹）として顎動脈から起始。

Type V. 舌動脈と顔面動脈は分離して䪽動脈 


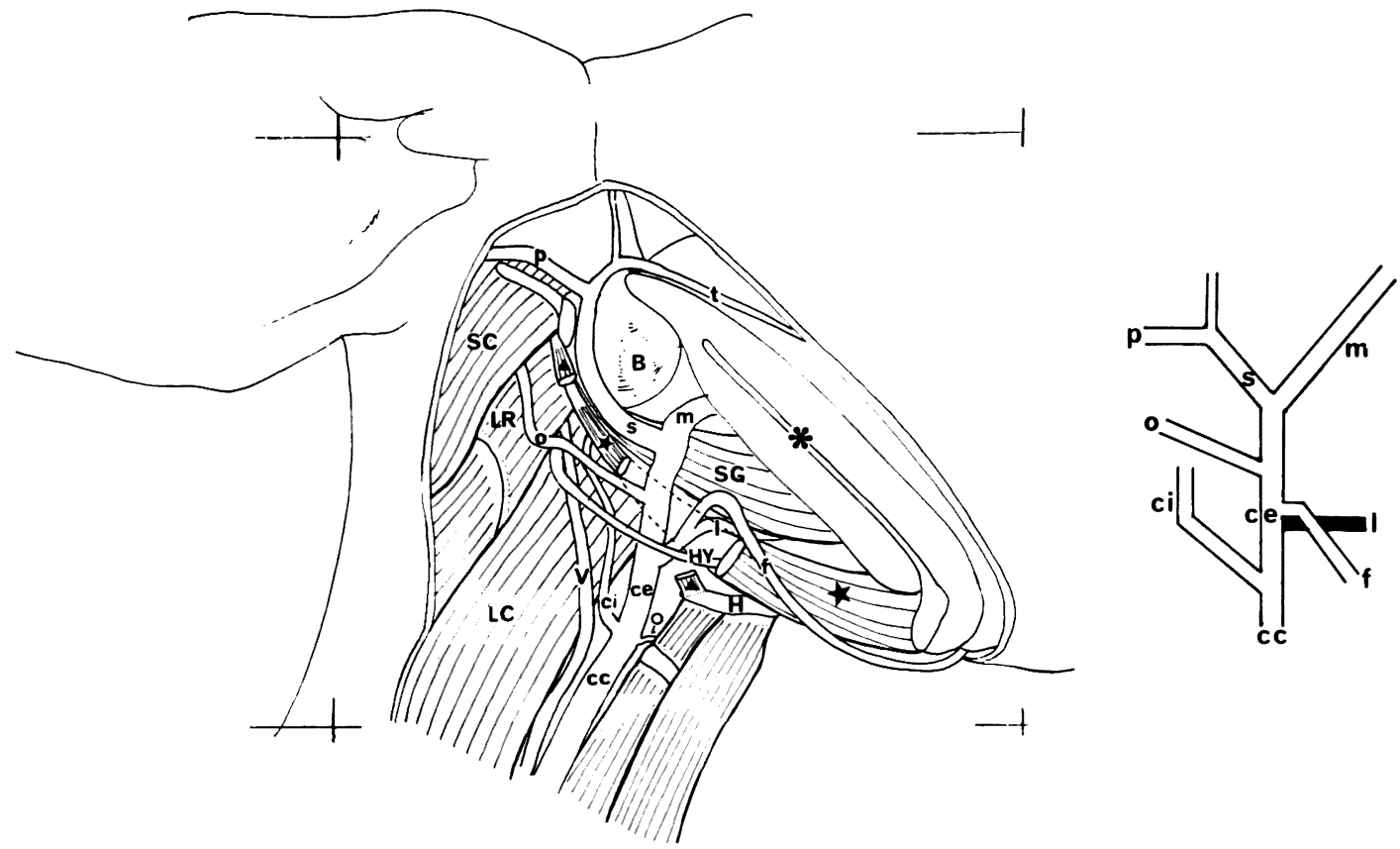

cc : Common carotid artery

ce: External carotid artery

ci : Internal carotid artery

f: Facial artery

1: Lingual artery

m : Maxillary artery

o: Occipital artery

p : Posterior auricular artery

s: Superficial temporal artery

$t$ : Transverse facial artery

$O$ : Superior laryngeal artery

$\rightarrow$ : Direction of the snout

B : Tympanic bulla

Key to abbreviations for figures

$\mathrm{H}$ : Hyoid bone

HY : Hypoglossal nerve

LC : Longus capitis muscle

LR: Rectus capitis lateralis muscle

SC: Semispinalis capitis muscle

SG: Styloglossus muscle

$\mathrm{V}$ : Vagus nerve

$\star$ : Digastricus muscle

A : Stylohyoideus muscle

*: Cross sections of the mandible, the masseter and the pterygoideus medialis muscles.

Fig 1 Schematic illustration of ramifications of the external carotid artery of the rabbit, refering to Type ID.

から起始。

一方, 後頭動脈の親動脈についてはつぎのよう

に6 Types に分類した。

Type A. 椎骨動脈から起始する後頭動脈。

Type B. 内頸動脈から起始する後頭動脈。

Type C. 外頸動脈の第 1 枝として起始する後 頭動脈。

Type D. 外頸動脈の第 2 枝として起始する後 頭動脈。

Type E. 後耳介動脈から起始する後頭動脈。

Type F. 浅側頭動脈から起始する後頭動脈。
III. 浅側頭動脈と顎動脈の分岐位置と走行

Type I A (Fig. 11), B, C (Fig. 9), D (Figs. 1, 2), E および Type II A, B (Fig. 3), C, D の全例においては, 両動脈の分岐は茥突舌 筋と顎二腹筋の間の外側に位置し，顎動脈は上方 人, 浅側頭動脈は後上方へ向っていた。

Type III A (Fig. 10), B (Fig. 4), C (Figs. 6，12)，D，E および Type IVB においては両動 脈の分岐は顎二腹筋の上内側方に位置し，顎動脈 は上外側方人，浅側頭動脈は上後外側方一向って いた。 
Type IIIF (Fig. 13) と IVF (Fig. 7) および Type VC においては両動脈の分岐は顎二腹筋の 内側に位置し，顎動脈は前上方へついで上外側方 へ曲がり, 浅側頭動脈は後上方へついで上後外側 方へ曲がっていた。

Type VF（Fig. 5) においては両動脈の分岐は さらに近位 (低位), つまり本来舌動脈または舌顔 面動脈（幹）の起始する高さ, 寸なわち舌骨大角 の後上内側方, かつ舌下神経の内側に位置してい た。顎動脈は前上方へ 頡二腹筋内側を上方へ走 り，その上縁で上外側方へ曲っていた。このよう な例では顎二腹筋と茎突舌筋の間を上外側方 それらの外側にでて茎突舌筋の外側縁にそって上 方へ曲り，ついで前内側方へ茎突舌筋の上方を前 上内側方へ走っていた。一方, 浅側頭動脈は後上 方一顎二腹筋内側を上行し, その上縁で後上外側 方へ曲り，茎突舌筋と顎二腹筋の間から外側に出 て, 後上外側方へ走っていた。

IV. 舌顔面動脈（幹）の起始と走行

Type I においては舌顔面動脈 (幹) は舌骨大 角の後上内側, 舌下神経の内側で外頸動脈の前壁 または前内側壁から前上方へ起始し (Figs. 2，8， 9), 直ちに舌動脈と顔面動脈に分岐していた。舌 動脈は前上内側方一, 顔面動脈は前上外側方一向 い顎二腹筋と茎突舌筋の間を外側へ，ついで前下 外側方へ向っていた。しかし Type ICにおいて は舌顔面動脈はやや遠位 (高位)，䪽二腹筋の内側 で外頸動脈の前壁から前方へ起始し（Fig. 11）, 前内側方へ向う舌動脈と前上外側方ついで前下外 側方一向う顔面動脈とに分岐していた。

Type IV においては, 舌顔面動脈（幹）は顎二 腹筋の上内側で顎動脈の 前壁から前方へ起始し (Fig. 7)，直ちに舌動脈と顔面動脈に分岐してい た。

\section{V. 舌動脈の起始と走行}

Type II およびIIIにおいては舌動脈は外頸動脈 から起始していた(Figs. 3，4，6，10，13)。舌動脈 の 起始位置は前述の舌顔面動脈(幹)のそれと同じ で，外頸動脈の前壁または前内側壁から前上内側 方へ起始し, 顎二腹笳内側を前上方へ走り, 茎突舌 筋の下方で前内側方に曲り舌尖に向かっていた。 しかし Type IIC と Type III (Figs. 6, 12)
における舌動脈は，效二腹筋の内側で外頸動脈の 第 2 枝として前内側壁から前内側方へ起始し，そ のまま舌尖に向っていた。

Type Vにおいては舌動脈は顎動脈から起始し ていた（Fig. 5)。外頸動脈は近位（低位）で 2 終 枝に分岐しており，舌動脈は顎二腹筋内側で顎動 脈の前内側壁から前内側方一起始し，そのまま舌 尖に向っていた。

\section{VI. 顔面動脈の起始と走行}

Type II においては顔面動脈は外頸動脈から起 始し（Fig. 3), 顎二腹筋の内側, または本筋と茎 突舌筋間で外頸動脈の前外側壁から前上外側方 向かい，茎突舌筋と䫟二腹筋の間を外側方へ，さ らに前下外側方へ向っていた。

Type IICにおいては, 顔面動脈は顎二腹筋の 上外側で外頸動脈の前壁から前下外側方へ向って いた。

Type III A (Fig. 10), B (Fig. 4), C (Fig.23), D, E および Type VF（Fig. 5) においては顔面 動脈は顎動脈から起始し，顎動脈が茥突舌筋と䪽 二腹筋間を前上外側方へ，その外側に出て上方に 曲がるとき，その前外側壁から前下外側方へ起始 し直線的に走行していた。

Type IIIF (Fig. 13) および Type VCにおい ては顔面動脈は顎二腹筋の上内側で顎動脈の 前外 側壁から前上外側方に起始し，顎動脈と同じく䫟 二腹筋と茎突舌筋閒を外側にでて前下外側方へ 走 っていた。

VII. 後頭動脈の起始とその走行

Type A においては後頭動脈は椎骨動脈から起 始していた (Figs. 9, 10)。後頭動脈は椎骨動脈が 環椎の横突孔をでて後上内側方へ曲がり椎骨動脈 孔に入る直前で，上外側方または前上方へ起始し ていた。前者の方向をとる後頭動脈は外側頭直筋 と上頭斜筋の間を上外側方へ(Fig. 9), 後者の方 向をとる後頭動脈は環椎と外側頭直筋の間を前上 方へ(Fig. 10), 外側頭直筋前内側で外側方に曲が り，その前縁にそって外側方へ，ついで後上内側 方へ曲がり同筋の後面，すなわち同筋と頭半棘筋 との間に達していた。

Type B においては内頸動脈は総頸動脈から起 始し, 後上方へ頭長筋外側を横切り耳胞内側の 頸 
動脈管に向っていた。その走行中, 後頭動脈が内頸 動脈の後壁から後上方へ起始し, 内頸動脈のうし ろを上行し耳胞の後内側に達していた（Figs. 3, 4)。後頭動脈の起始が近位に偏している例では迷 走神経や舌下神経の内側を通っていたが，遠位に 偏している例では迷走神経の内側, 舌下神経の外 側を通っていた (Fig. 4)。そののち後頭動脈は外 側頭直筋の前方で下外側方へ曲がり，上述のよう な走向をとっていた。

Type Cにおいては後頭動脈は外頸動脈の第 1 枝として (Figs. 6,11，12), 舌骨大角の後上内側 かつ舌下神経の内側で外頸動脈の後壁から 後上方 へ起始していた。Type D たおいては後頭動脈は 外颈動脈の第 2 枝として (Fig. 2), 舌動脈または 舌顔面動脈（幹）起始のすぐ遠位, 顎二腹筋の内 側で外頸動脈の後壁から後上方へ起始し, 茎突舌 筋と舌下神経間を後上方へ走り（Figs. 11，12）, 耳胞の後内側で内頸動脈の外側を横切り, 舌下神 経と迷走神経の外側をへて外側頭直筋の前面に 達 していた。その後頭動脈の走行は Type B と同様 であった。Type IIC および Type IIIC それぞれ の1例においては, 後頭動脈は内頸動脈起始のす ぐ遠位で外頸動脈の後内側壁から後方へ 起始し, 内顓動脈の内側を後方へ走っていた。

Type VCにおいては後頭動脈は内頸動脈起始 のすぐ遠位に接して上方へ起始し, 内頸動脈の外 側を後上方へ走っていた。Type E においては後 頭動脈は胸骨乳突筋停止の外側で後耳介動脈の下 壁から起始し（Fig. 8), 後下方に向い, 本筋後縁 をまわって前内側方へ本箭と頭半棘筋の間から頭 半棘筋前縁を後上内側方に弧状に走り, 頭半棘笳 と外側頭直筋の間を走行していた。このような後 頭動脈には頭長筋枝の派出は認められず, 内頸動 脈から派出していた。

Type F においては後頭動脈は顎二腹筋の上内 側で浅側頭動脈の後壁から後上方へ起始し（Figs. $5,7,13)$, 茎突舌筋と舌下神経の間を後上方へ走 り, 内頸動脈の外側を横切って耳胞の後内側方に 達し, 舌下神経と迷走神経の外側をへて外側頭直 筋の前面に達していた。その後の後頭動脈の走向 は Type B と同様であった。

\section{考察}

実験動物として多用されるカイウサギの外頸動 脈の主要な分枝である後頭動脈, 舌動脈, 顔面動 脈ならびにその終枝である浅側頭動脈と顎動脈も 加えて, それらの起始様相は複雑な相関関係をも っている。このような状態に注目した研究者は著 者だけでなく先人達も大いに関心をよせてきた。

Krause (1884) ${ }^{4}$, Baldwin (1919) ${ }^{11}$, Bensley $(1948)^{5)}$ はカイウサギの外頸動脈の分枝状況の概 要を記載した。つまり外頸動脈からは後頭動脈, 舌動脈, 顔面動脈が順に派出したのち, 浅側頭動 脈と顎動脈に分岐するとした。さらに Baldwin はそれらの分枝状況の変化を模式図で示した。

哺乳動物では一般に外頸動脈の終枝は顎動脈と 浅側頭動脈 とされている。その終枝分岐の位置 (高さ) は顎二腹筋の上内側方, 下顎頸の後方, かつ 外耳道の前下外側方である。Bensley や Baldwin はカイウサギの外頸動脈もこの両動脈を終枝と記 述している。しかし，これに関してつぎのような 別の見解がみられる。

Bugge $(1969)^{8)}$, Ryumon (1970) 》 はカイウサ ギの外頸動脈は顎動脈を派出後, さらに上行して 下顎頸の後方, 外耳道の前下方で後耳介動脈と浅 側頭動脈に分岐すると述べた。つまり後耳介動脈 派出後の部分を浅側頭動脈としたのである。

著者の見解では，2 終枝分岐までのカイウサギ の外頸動脈固有の長さが短いことと，巨大な耳介 一血液を供給する後耳介動脈が強大であること が，外頸動脈の諸分枝の起始を多様化させた原因 であると考えられる。先人らの見解と対比してみ

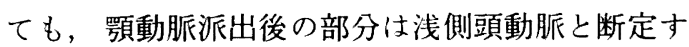
べきものと考え，観察と考察を進めたものであ る。比較解剖学的に浅側頭動脈と後耳介動脈の分 岐についてみてみると, Matsumoto (1983) $)^{81}$ はネ コで外頸動脈が後耳介動脈と浅側頭動脈の共通幹 と顎動脈に分岐した例を報告している。この報告 例はまさに著者のカイウサギの通常分岐型に相当 するものである。

著者は起始位置の変化の少ない舌動脈を基準に とり, 逆にその変化が多く現われる後頭動脈の様 相について，それぞれ分類を試み両者を相関させ 
たのが Table 1 である。この分類と Baldwin" の12型（ $\mathrm{B}_{1} \sim \mathrm{B}_{12}$ で示す）とを対比してみるとつ ぎのようである。 Type IIC は Baldwin が基本 型としている $\mathrm{B}_{1}$ に相当する。しかしながら奇異 なことには，このような型は著者の全観察 740 例 中ただ 2 例にのみ認められたに過ぎない。そして Type I D は Baldwin の $\mathrm{B}_{4}$ または $\mathrm{B}_{9}$ に相当 し，著者の観察結果ではこの例が最も多いので基 本型であると考えた。そのほかの Type について 対比してみると, Type I B は $\mathrm{B}_{2}$ または $\mathrm{B}_{12}$ に, Type II B は $\mathrm{B}_{7}$ に, Type IIIC は $\mathrm{B}_{6}$ に, Type I C は $\mathrm{B}_{8}$ に，それぞれ一致している。し かし，これ以外の Type については Baldwin の 分類と多少相違していた。このような推移からみ て，カイウサギの外頸動脈諸分枝の分枝状況は常 に複雑で variation が多いといえる。

後頭動脈はイヌ (Nickel et al. 1976, ${ }^{9)}$ Evans et al. 1979) ${ }^{10)}$ やウマ(Nickel et al.) では外頸動 脈の第 1 枝であるが，カイウサギの多数例では第 2 枝として派出されている。そしてカイウサギで は Kaneko $\left(1970^{111}\right)$ と Kamakura $(1970)^{12)}$ が 記述したように，後頭動脈が内頸動脈から派出す る例が多く認められた。Kaneko, Mori (1986) ${ }^{131}$ はイヌにおいても後頭動脈の内頸動脈起始を 報告 している。ブタやウシ，一部のネコでは後頭動脈 は内頸動脈から起始している(Nickel et al.)。一 方，ヒトでは Adachi (1928) ${ }^{14)}$ がこのような 1 例 を報告し，鈴木ら $(1980)^{15}$ は後頭動脈が内頸動 脈から起始する場合についてX線観察を行ない発 生学的考察をめぐらしている。後頭動脈が椎骨動 脈から起始する例についてみると，ヤギ（Kamakura) ${ }^{12)}$ では常に，またヒト (都筑ら1980) ${ }^{16)}$ で はときに，外頸動脈から起始し，椎骨動脈と強く 吻合し， あたかも椎骨動脈の分枝のようにみえる 例が示されている。しかし，カイウサギではこの ような吻合は全く認められなかった。一方，サル (Dyrud 194417), Castelli et al. 1965 ${ }^{18)}$ ) で, Adachi $^{14)}$ はヒトの $13.9 \%$ で後頭動脈と後耳介動 脈が共通幹で外頸動脈から派出するとしている。 しかし，カイウサギでは後頭動脈が後耳介動脈か ら起始する例がみられたが，これは後耳介動脈が 強大なためである。浅側頭動脈から起始する後頭
動脈は，カイウサギ特有の形態で他の動物種につ いては記載をみない。ただカイウサギについては Kamakura が著者と同様な記述をしているのみで ある。

舌動脈と 顔面動脈の相関関倸についてみると, カイウサギでは 両動脈が 舌顔面動脈（幹）を形 成して外頸動脈から 派出する 例が極めて多く認 められた。そして本研究でみられた特異な例は この共通幹が顎動脈から起始している 7 例であ る。このような 䪽動脈起始については Bugge $(1969)^{6)}$ が linguofaciomaxillary trunk $(5 \%)$ を 記載している。外頸動脈から起始する舌顔面動脈 （幹）(Dyrud ${ }^{17)}$, Castelli et al. ${ }^{18)}$, 花井ら $1976^{191}$ ) はカニクイザルでは全観察例に，また Yamamoto $(1979)^{20)}$ は同様の共通幹が通常例であるとして いる。また Bensley はカイウサギではときに舌顔 面動脈（幹）を形成するが，多くの場合両者は分 離して起始すると述べた。Okano $(1960)^{21)}$ はネ コでこのような舌顔面動脈（幹）の存在を報告し ている。 Nickel et al. はウシ, ウマで本動脈幹 を全例で，Adachi ${ }^{14)}$ はヒトで約 $18.7 \%$ にその存 在を認めている。舌動脈と顔面動脈がたがいに分 離して起始する場合，両者が外頸動脈から派出す るのが哺乳動物の一般的な分岐型である。しかし ながら，カイウサギでこのような分岐型を認め る場合は, 顔面動脈の起始 は顎動脈であった。 Bugge $^{6)}$ はこのような起始を faciomaxillary trunk とし，30\%にみられるとしている。

上述のような舌動脈と顔面動脈が分離または共 通幹で䫑動脈から起始する22例では，外頸動脈の 2 終枝分岐位置が近位(低位)に偏しており，さら にそのうち20例では後頭動脈は浅側頭動脈から 起 始していた。したがって，このような例では外頸 動脈からはなんらの分枝の派出をみない。

\section{結 論}

カイウサギの外頸動脈の分枝状況をアクリル 樹 脂注入法によって観察した。

1. 全観察740例について, 外頸動脈 の 2 終枝 分岐位置, 舌動脈, 顔面動脈（5 型）ならびに後 頭動脈（6 型）それぞれの起始様相について分類 し，相関関係を調べた。 
2. カウウサギの外頸動脈の 2 終枝分岐位置 は，一般に下顎枝中央の高さで顎二腹筋と茎突舌 筋間の外側であった。しかし，その高さが近位 （低位）の場合, 外頸動脈の諸分枝の 起始様相に いろいろの変化が認められた。

3. 舌動脈と顔面動脈は舌顔面動脈（幹）とし て起始することが多かった。舌動脈と顔面動脈が それぞれ単独で起始する例では, 後者が顎動脈か ら起始することが多く，この場合外頸動脈の 2 終 枝分岐位置はより近位（低位）であった。

4. 後頭動脈の起始は外頸動脈の 2 終枝分岐位
置の変化とは関倸がなく，外頸動脈または内頸動 脈であった。しかし 2 終分岐位置が極めて近位 (低位)の例では後頭動脈は浅側頭動脈から起始し ていた。

本論文を終わるにあたり，ご指導ここ校閲をいただ た太田義邦教授に深䍘の謝意を表するとともに，有益な ご助言をいただいた解剖学教室員各位に厚く㧍礼申し上 げます。

本論文の要旨は第92回日本解剖学会総会（1987年 4 月 2 日）㧍上び第360回大阪菌科学会例会（1987 年 9 月 13 日）汇㧍いて発表した。

抄録：カイウサギの外頸動脈の分枝状況をアクリル樹脂注入法によって，成熟カイウサギ740側について観 察した。外頸動脈の主要分枝として舌動脈, 顔面動脈, 後頭動脈が認められた。舌動脈の起始様相を 5 型に 分類し，これと他の分枝ならびに後頭動脈の起始源（6 型）を考虑して外頸動脈諸分枝との相関関係を総括 した。総頸動脈は第 1 頸椎中央の高さで内頸動脈と外頸動脈に分岐していた。外頸動脈は，顎二腹筋と茎突 舌筋の間を通って，それらの外側に出て下頡枝中央の高さで顎動脈と浅側頭動脈の 2 終枝に分岐していた。し かし，この分岐位置がより近位（低位）のものも認められた。舌動脈と顔面動脈は外頸動脈まれに顎動脈か ら，舌顔面動脈（幹）をへて，または単独で起始していた。とくに顔面動脈が䫁動脈から起始する場合は外 颛動脈の 2 終技分岐位置がより近位（低位）であった。一方，後頭動脈は椎骨動脈，内顓動脈，外顓動脈（第 1 枝または第 2 枝)，後耳介動脈，浅側頭動脈のいずれかから起始していた。外頸動脈の 2 終枝分岐の位置が より近位（低位）で外頸動脈が短い例では外頸動脈からの分枝は認められなかった。

\section{文献}

1) Baldwin, F. M.: Variations in the carotid arteries of the rabbit. Anat. Rec. $16: 309$ $315,1919$.

2) Taniguchi, Y., Y. Ohta \& S. Tajiri.: New improved method for injection of acrylic resin. Okajimas Folia Anat. Jpn. 24 : 259267, 1952.

3) Taniguchi, Y., Y. Ohta, S. Tajiri, H. Okano, H. Hanai : Supplement to new improved method for injection of acrylic resin. Okajimas Folia Anat. Jpn. 27 : 401-406, 1955.

4) Krause, W.: Anatomie des Kaninchens in topographischer und operativer Rücksicht. Zweite Auflage, s. 80-84, 252, 253, Leipzig, Wilhelm Engelmann, 1884.

5) Bensley, B. A. : Practical anatomy of rabbit. 8 th ed., pp. 302-305, Blakiston Co., Phila., 1948.

6) Bugge, J.: The cephalic arterial system in the rabbit with special reference to muscles of mastication and temporomandibular joint. Acta Anat., 72 : 109-122, 1969.

7) Ryumon, A.: Stereological studies of sever- al ducts and vessels by injection method of acrylic resin. XXVII. On the superficial tem. poral artery in some mammals. Okajimas Folia Anat. Jpn. $47: 353-374,1970$.

8) Matsumoto, M : The posterior auricular artery of the cat. Okajimas Folia Anat. Jpn. 243-268, 1983.

9) Nickel, R., A. Schummer \& \& E. Seiferle. : Lehrbuch der Anatomie der Haustiere. Bd. III, s. 76-190, Paul Parey, Berlin, 1976.

10) Evans H. E. and Christensen G. C. : Miller's anatomy of the dog. pp. 632-756, W. B. Saunders, Phila., 1979.

11) Kaneko, S. : Stereological studies on several ducts and vessels by injection method of acrylic resin. XXIV. On the internal carotid artery in dog, rabbit and human fetus. Okajimas Folia Anat. Jpn., 47: 193-212, 1970.

12) Kamakura, K.: Stereological studies on several ducts and vessels by injection method of acrylic resin, $\mathrm{XXV}$. On the occipital artery in some mammals. Okajimas Folia Anat. Jpn., $47: 289-317,1970$.

13) Mori, T.: The ascending pharyngeal artery of the dog. Okajimas Folia Anat. Jpn., 62 : 
241-260, 1986.

14) Adachi, B.: Arteriensystem der Japaner. Bd. 1 : s. 76-77, 82-85, Maruzen Co., Kyoto, 1928.

15）鈴木宗治, 桑原堆二：proatlantal intersegmentar artery と内頸動脈起始の後頭動脈との関係 についての考察. 臨放 $25:$ 178-179, 1980.

16）都筑文男, 藤村 朗, 横須賀均, 大沢得二, 伊 藤一三, 野坂洋一郎 : 後頭・椎骨動脈の 1 例. 岩医大歯誌・5 : $3: 208,1980$.

17) Dyrud, J.: The external carotid artery of the rhesus monkey (macaca mulatta). Anat. Rec. 90 : 19-22, 1944.

18) Castelli, W. A. and Huelke, D. F.: The arterial system of the head and neck of the rhesus monkey with emphasis on the external carotid system. Am. J. Anat. $116: 149$ $170,1965$.

19）花井 汎, 花井 隆, 大塚晴雄, 山中 章: 力 ニクイザルの顔面動脈とその分枝について. 城 歯大紀要. 5 : 13-20, 1976.

20) Yamamoto M.: The arterial supply of the submandibular gland of the crab-eating monkey. J. Osaka Dent. Univ. 13 : 1-24, 1979.

21) Okano, H.: Cubical anatomy of several ducts and vessels by injection method of acrylic resin. VII. On the ramification of $\mathrm{A}$. lingualis and its fine distribution in some mammals. Okajimas Folia Anat. Jpn. 34 : 233-297, 1960. 


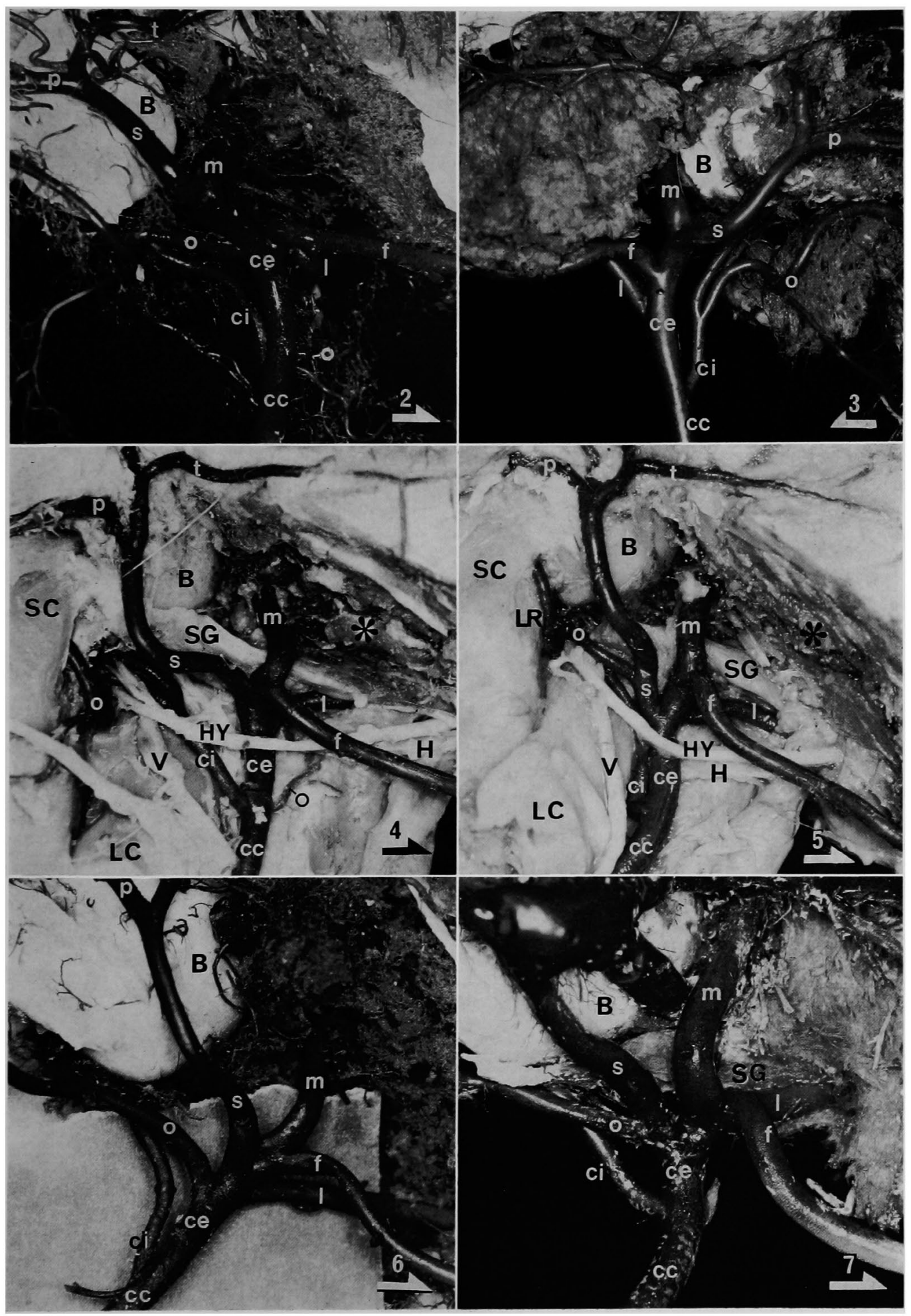




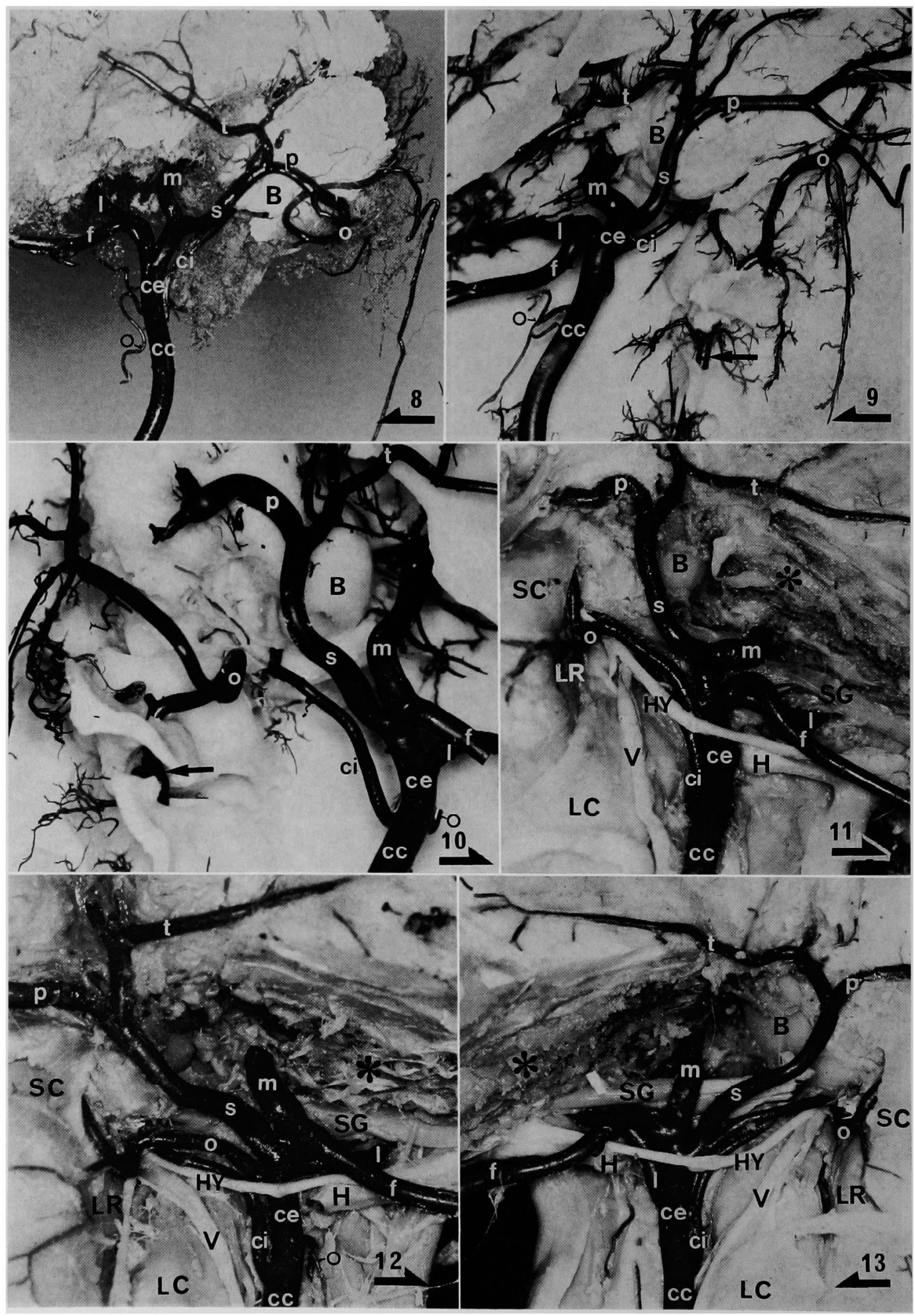


Key to abbreviations for figures

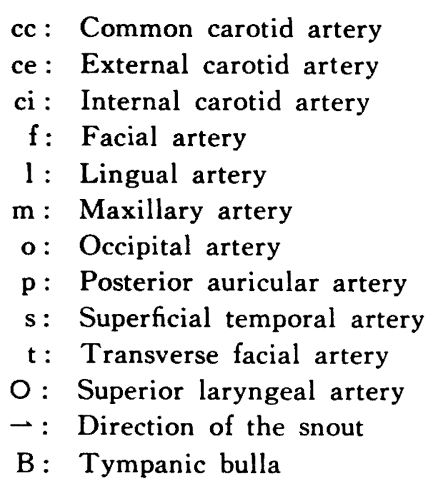

Plate I.

Fig. 2. Lateral view of ramifications of the external carotid artery (right side). $\times 2.1$.

Type ID, being most frequent in all the examples observed, in which the linguofacial trunk and the occipital artery arise from the external carotid.

Fig. 3. Lateral view of ramifications of the external carotid artery (left side). $\times 2.1$.

Type IIB, in which the lingual and the facial arise separately from the external carotid, and the occipital from the internal carotid.

Figs. 4 and 5. Topographic relations between ramifications of the external carotid and surrounding structures (right side). $\times 2.2, \times 2.4$.

The mandibular angle, the digastricus and the stylohyoideus are removed.

The position mentioned above shown as Type VF in Fig. 5, is much more proximal. The lingual and facial arise from the maxillary, and the occipital from the superficial temporal.

Figs. 6 and 7. Lateral view of ramifications of the external carotid (right side.) $\times 3.4, \times 3.4$.

Type IIIC in Fig. 6, in which arising features of the lingual and the facial arteries are similar to those in Fig. 4, but the occipital arises from the external carotid.

Type IVF in Fig. 7, in which ramifications of the external carotid are similar to those in Fig. 5, but the lingual and the facial arteries arise via the linguofacial trunk from the maxillary.

Plate II.

Figs. 8,9 and 10. Lateral view of ramifications of the external carotid (Figs. 8 and 9 are the left side, Fig. 10 the right side). $\times 1.3, \times 1.5, \times 2.2$.

Type IE in Fig. 8 , in which the occipital always runs in the shape of a peculiar loop in any cases of this type.

Type IA in Fig. 9 and Type IIIA in Fig. 10, in which two different courses of the occipital arising from the vertebral artery $(\leftarrow)$ are seen.

Figs. 11, 12 and 13. Topographic relations between ramifications of the external carotid and surrounding structures. (Figs. 11 and 12 are right side and Fig. 13 left side). $\times 2.4, \times 2.3, \times 2.1$. Type IC in Fig. 11, Type IIIC in Fig. 12 and Type IIIF in Fig. 13, in which each position of the terminal bifurcation of the external carotid move proximally in this order as shown in Figs. 11,12 and 13.

According to such an alteration, variations are seen in arising features of the other arteries as follows: The occipital in Figs. 11 and 12 arises from the external carotid, that in Fig. 13 from the superficial temporal. The linguofacial trunk in Fig. 11 arises from the external carotid, and the lingual in Figs. 12 and 13 from the external carotid, and the facial from the maxillary. 